\title{
Traversing the Fantasy of the Heroic Entrepreneur
}

\author{
Garmann Johnsen, Christian; Sørensen, Bent Meier
}

Document Version

Accepted author manuscript

Published in:

International Journal of Entrepreneurial Behavior \& Research

DOI:

10.1108/IJEBR-01-2016-0032

Publication date:

2017

License

Unspecified

Citation for published version (APA):

Garmann Johnsen, C., \& Sørensen, B. M. (2017). Traversing the Fantasy of the Heroic Entrepreneur. International Journal of Entrepreneurial Behavior \& Research, 23(2), 228-244. https://doi.org/10.1108/IJEBR-012016-0032

Link to publication in CBS Research Portal

\section{General rights}

Copyright and moral rights for the publications made accessible in the public portal are retained by the authors and/or other copyright owners and it is a condition of accessing publications that users recognise and abide by the legal requirements associated with these rights.

Take down policy

If you believe that this document breaches copyright please contact us (research.lib@cbs.dk) providing details, and we will remove access to the work immediately and investigate your claim. 


\title{
Traversing the Fantasy of the Heroic Entrepreneur Christian Garmann Johnsen and Bent Meier Sorensen
}

\author{
Journal article (Accepted manuscript)
}

CITE: Traversing the Fantasy of the Heroic Entrepreneur. / Garmann Johnsen, Christian; Sarensen, Bent Meier. In: International Journal of Entrepreneurial Behavior \& Research, Vol. 23, No. 2, २०17, р. 228-244.

This article is [C Emerald Group Publishing and permission has been granted for this version to appear here: https://research.cbs.dk/en/publications/traversing-the-fantasy-of-the-heroic-entrepreneur. Emerald does not grant permission for this article to be further copied/distributed or hosted elsewhere without the express permission from Emerald Group Publishing Limited.

DOI: 10.1108//JEBR-01-2016-0032

Uploaded to CBS Research Portal: January २०19 


\title{
Traversing the Fantasy of the Heroic Entrepreneur
}

\author{
Christian Garmann Johnsen \\ Department of Management, Politics and Philosophy \\ Copenhagen Business School, Denmark \\ cgj.mpp@cbs.dk \\ Bent Meier Sørensen \\ Department of Management, Politics and Philosophy \\ Copenhagen Business School, Denmark \\ bem.mpp@cbs.dk
}

\begin{abstract}
Purpose: While considerable critical energy has been devoted to unmasking the figure of the heroic entrepreneur, the idea that entrepreneurs are unique individuals with special abilities continues to be widespread in scholarly research, social media and popular culture. The purpose of this paper is to traverse the fantasy of the heroic entrepreneur by offering a reading of Richard Branson's autobiography, Losing My Virginity.
\end{abstract}

Design/methodology/approach: The theoretical approach of this paper is informed by Slavoj Žižek's concept of fantasy and his critical analytical strategy of 'traversing the fantasy'. Žižek offers a theoretical framework that allows us to understand how narratives of famous entrepreneurs create paradoxical fantasies that produce desire.

Findings: By offering a reading of Richard Branson's autobiography, Losing My Virginity, this paper serves to illustrate how the fantasy of the heroic entrepreneur creates the injunction to overcome oneself and become true to oneself, but also how this figure is ridden with contradictions and impossibilities. Branson's book will eventually be shown to be a religious narrative, where the entrepreneur is responsible for redeeming the crises not only of the economy, but of being as such. 
Originality/value: Rather than striving towards a processual approach that lays emphasis on the collective effort involved in entrepreneurship, this paper critically engages directly with the heroic entrepreneur by exploring how this figure is a fantasy that structures desire. This paper shows how critical entrepreneurship studies could benefit from an approach that analyses how the cultural representation of business celebrates the heroic entrepreneur as a source of value creation. We further argue that it is the contradictions and impossibilities embodied in the figure of the heroic entrepreneur that carry its far-reaching appeal.

Keywords. Critical entrepreneurship studies, entrepreneurial narratives, paradox, fantasy, Žižek

\section{Introduction}

In 1988, Gartner criticized mainstream entrepreneurship studies for asking 'Who is an entrepreneur?', claiming that the question was loaded with erroneous presumptions (Gartner, 1988). Traditional trait-based research had assumed that entrepreneurs share a common set of characteristics, such as the propensity for 'risk-taking' (Brockhaus, 1980) or a high degree of 'self-reliance' (Sexton and Bowman, 1985), from which one could crystalize a generic entrepreneurial personality. Yet empirical studies has tended to argue that that 'there is no “typical” entrepreneur' (Bull and Willard, 1993: 187). According to Gartner (1988), the failure to

pin down the essence of the entrepreneurial personality was due to a misguided theoretical approach. Instead of mapping the traits of entrepreneurs, Gartner suggested that scholars should pay attention to the entrepreneurial process, which he conceptualized as the 'creation of organization' (1988: 57; see also Hjorth et al., 2015; Katz and Gartner, 1988). Using various theoretical perspectives (Steyaert, 2007a), entrepreneurship scholars have shifted to investigating the sequence of activities associated with entrepreneurship. This line of research has 'done everything to draw the attention away from the individual entrepreneur in order to make space for understanding the complexity of the entrepreneurial process' (Steyaert, 2007b: 734).

Despite his emphasis on the importance of focusing on the entrepreneurial process instead of the entrepreneurial personality, Gartner cautiously maintains that it 'is difficult not to think' that entrepreneurs are 'special people who achieve things that most of us do not achieve' and that 
their accomplishments are 'based on some special inner quality' (1988: 58, emphasis in original). The figure of the entrepreneur is frequently portrayed as that of a 'heroic creator' (Steyaert, 2007a). Such heroic renderings are often criticized for being ethnocentric (Ogbor, 2000), genderbiased (Calas et al., 2009) and Westernized (Costa and Saraiva, 2012). In effect, critical scholars have emphasized precisely those aspects of entrepreneurship that are overlooked by conventional conceptions (Ahl, 2006; Verduijn and Essers, 2013; Williams and Nadin, 2013). However, while considerable critical energy has been devoted to unmasking the figure of the heroic entrepreneur (Armstrong, 2005; Jones and Spicer, 2009; Ogbor, 2000), the idea that entrepreneurs are unique individuals with special abilities continues to be widespread in social media and popular culture (Drakopoulou Dodd and Anderson, 2007). Tedmanson et al. note that in the wake of the global financial crisis, one might have expected 'some drastic rethink of the unquestioning idealization of the entrepreneur' (2012: 531). But this has not been the case. On the contrary, heroic images of entrepreneurs, such as Mark Zuckerberg, Steve Jobs, Bill Gates and Richard Branson still seem to dominate the general perception of entrepreneurship. While particular entrepreneurs have failed, the 'entrepreneurial dream lives on!' (Tedmanson.et al., 2012: 532; see also Olaison and Sørensen, 2014). Even through his glorious failures, the entrepreneur shows that failure marks the path of the righteous, making him the redeemer of the economy (Sørensen, 2008).

This paper is concerned with the difficulty of thinking beyond the figure of the heroic entrepreneur. To address this difficulty, the paper introduces the Slovenian philosopher Slavoj Žižek's concept of 'fantasy'. As such, the paper follows the tradition of 'The European School of Entrepreneurship' in embracing ideas from philosophy in the study of entrepreneurship (see Down, 2013; Gartner, 2013; Hjorth et al., 2008). Today, Žižek is one of the world's most renowned continental philosophers, with a project of converting Lacanian psychoanalysis into a cultural theory. Here we demonstrate the relevance of using Žižek's concept of fantasy to engage with cultural representations of the heroic entrepreneur. What Žižek has to offer is a theoretical framework that allows us to understand how narratives of famous entrepreneurs create fantasies that produce desire (Jones and Spicer, 2005). According to Žižek, the particular role of fantasy is to condition and structure our drives, passions and desires. For Žižek, fantasy does not represent an imagined scenario wherein we attain the things we desire that are unachievable in real life. Rather, 'a fantasy constitutes our desire, provides its co-ordinates, that is, it literally "teaches us 
how to desire"' (Žižek, 1997: 7). Thus, fantasies are narratives that encourage us to want or long for certain things. As we will show in this paper, such fantasies can be located in the narratives of heroic entrepreneurs insofar as they create structures of desire that teach us how to desire to become an entrepreneur.

While much critical work tends to either look beyond or beneath the fantasy of the heroic entrepreneur, emphasizing those aspects of entrepreneurship overlooked by the figure of the heroic entrepreneur, this paper develops a complementary critical strategy. Instead of eschewing the fantasy of the heroic entrepreneur, this paper will confront the fantasy itself by drawing on Žižek's idea of 'traversing the fantasy'. Traversing the fantasy, according to Žižek, does not mean to see 'through [the fantasy] and perceive the reality obfuscated by it, but to directly confront the fantasy as such' (2014: 30). Thus, to traverse the fantasy basically entails to take the fantasy at its face value and spell out the implications that follow from it. To do this, the paper engages with one of the 'most famous and visually iconic entrepreneurs in the Western world' (Boje and Smith, 2010: 307), namely Sir Richard Branson. If there is a 'sublime object of entrepreneurship' (Jones and Spicer, 2005), then it is founder of the Virgin Group, who, Smith and Andersen claim, 'needs no introduction, being known worldwide' (2004: 134). As a way to engage with the heroic image of Branson, this paper engages in a selective reading of his autobiography Losing My Virginity, an international bestseller that has sold over two million copies worldwide. Here we explore how the narrative presented by Branson operates as a fantasy that constitutes structures of desire. We have therefore chosen to engage with Branson as an example of a heroic entrepreneur because of his iconic status in our time.

The purpose of engaging with Branson's autobiography Losing My Virginity is to critically confront the portrayal of the fantasy of the heroic entrepreneur as a cultural representation. For this reason, the paper takes inspiration in narrative approaches to entrepreneurship. Following Žižek, we will achieve this by viewing narratives as fantasies that coordinate desire. By identifying with the contradictions and impossibilities paraded in Losing My Virginity, we can explore what makes Branson's autobiography attractive. Narrative approaches to entrepreneurship have gained in number and momentum (e.g. Downing, 2005; Down, 2006; Gartner, 2007; Hjorth and Steyaert, 2004). As Steyaert explains, today 'there are so many stories, 
biographies, and myths told about and by entrepreneurs' present in society, making it fruitful to 'study them as cultural phenomena' (2007b: 743). Drawing attention to these stories has led to a 'narrative turn' (Hjorth, 2007) in entrepreneurship research. For instance, Cornelissen argues that studying biographies may provide 'new territory and new ways of theorizing about entrepreneurship' (2013: 701).

The paper proceeds as follows. The first part of the paper briefly reviews the critique directed at the figure of the heroic entrepreneur. While critics have argued that the figure of the heroic entrepreneur is an ideological construct, we will argue that it is better conceptualized as a fantasy that constitutes desire. The second part of the paper shows how Žižek's idea of 'traversing the fantasy' can be mobilized as a critical strategy for engaging with the figure of the heroic entrepreneur. The third part of the paper analyzes two anecdotes from Branson's autobiography informed by Žižek's idea of traversing the fantasy. We argue that these two stories operate as fantasies that constitute different structures of desire. On the one hand, Branson's narrative creates the desire for transgression (overcoming oneself). On the other hand, Branson's narrative creates the desire for authenticity (realizing oneself). These two structures of desire generate paradoxes in the mode of subjectivity conveyed by Branson's autobiography. The final part of the paper argues that Žižek's idea of traversing the fantasy opens up the possibility of formulating a critical strategy for confronting the idealized image of the entrepreneur prevalent in social media and popular culture, as well as interpreting the appeal that this figure continues to have today.

\section{The heroic entrepreneur}

Verduijn .et al. note that a "critical perspective can help unveil, disclose or realize what is often buried beneath or contained within the more "taken for granted" assumptions underpinning entrepreneurship studies' (2014: 99). Perhaps the most contested 'taken for granted' (Gartner, 2013: 5) assumption underlying traditional entrepreneurship research is the idea that the figure of the entrepreneur embodies 'ephemeral qualities - freedom of spirit, creativity, vision, zeal' (Burns, 2001: 1). As many have pointed out, entrepreneurs are often celebrated as the "heroic figurehead of capitalism' (Williams and Nadin, 2013: 552), capable of launching new products, 
services and modes of production into the economy. Yet, despite such focused attention on the figure of the entrepreneur, attempts to fully grasp the entrepreneurial personality have consistently proven to be unproductive (Jones and Spicer, 2005). As a result, entrepreneurship research has been marked by a 'lack of a conceptual framework' (Shane and Venkataraman, 2000) and a persistent inability to characterize the entrepreneurial personality (Shaver and Scott, 1991). The lack of a conceptual framework has rendered the concept of entrepreneurship vague, ambiguous and abstruse.

In the eyes of critical entrepreneurship scholars, the ambiguity pertaining to entrepreneurship has been exploited to serve ideological purposes. According to Armstrong (2001; 2005), entrepreneurship produces an illusory representation of reality that effectively distorts and obscures the actual material interests and power relations between social classes. Along similar lines, Ogbor argues that prevalent 'myths about the entrepreneur' serve to 'reinforce the existing power structure of the dominant groups in society' (2000: 607). In particular, Ogbor maintains that the dominant discourse on entrepreneurship conveys the 'myth' of the entrepreneur as a 'masculine' white male possessing 'super-normal qualities' (2000: 607). This myth effectively excludes other social groups from other social classes, a different gender and ethnicity. Jones and Spicer take Ogbor's (2000) and Armstrong's (2001) critiques one step further and claim that the persistent failure to theorize the essence of entrepreneurship shows, following Lacan, that the 'entrepreneur is a marker [...] of lack; the entrepreneur is indefinable, and necessary so; the entrepreneur is an "absent centre", (2005: 236).

As we can see, much of the critique against entrepreneurship is targeted toward the figure of the heroic entrepreneur (Jones and Spicer, 2005; Ogbor, 2000; Armstrong, 2001). As a consequence of the persistent failure to conceptualize entrepreneurship in terms of the figure of the heroic entrepreneur, many scholars have drawn attention to the entrepreneurial process. Shane and Venkataraman (2000) suggest that entrepreneurship should be conceptualized in relation to the exploitation of opportunities, a view that has sparked debates over the extent to which such entrepreneurial opportunities are created or discovered (Alvarez and Barney, 2007). Such a view, however, still remains tied to the idea of the individual entrepreneur insofar as it operates with the 'individual as the unit of analysis' (Alvarez and Barney, 2007: 23). As well, this view 
understands entrepreneurship primarily within an economic logic, ignoring the social, contextual and cultural aspects of the phenomena (Hjorth et al., 2008; Steyaert and Katz, 2004). As an alternative take, scholars associated with the European school have increasingly examined entrepreneurship as a process of organization-creation (see Gartner, 1988; Hjorth et al., 2015; Katz and Gartner, 1988; Steyaert, 2007a).

While the processual stream of research within the European school has focused on the collective effort involved in entrepreneurship, the figure of the heroic entrepreneur remains widespread in social media and popular culture (Drakopoulou, Dodd and Anderson, 2007). Revisiting Gartner's (1988) seminal critique of trait-based research, Steyaert (2007a) maintains that although previous research seeking the essence of the entrepreneurial personality has proven to be unsuccessful, asking the question 'Who is an entrepreneur?' is not without its merits. However, the question should not be formulated based on a notion of a generic entrepreneurial identity. Rather than assuming that the entrepreneurial personality can be characterized by set of unified traits, Steyaert (2007a) contends that the question should be approached from a narrative point of view, showing how the 'the stories that people tell' (Gartner, 2007: 613) constitute different modes of subjectivity. In the rest of this paper, we will therefore focus on the figure of the heroic entrepreneur from a narrative point of view. Indeed, a narrative approach allows us to explore how the figure of the heroic entrepreneur is symbolically constructed (Downing, 2005; Down, 2006; Gartner, 2007; Hjorth and Steyaert, 2004). To help us do so, we will introduce Žižek's concepts of fantasy and desire. This will allow us to see how narratives of heroic entrepreneurs circulating in social media and popular culture are fantasies that constitute desire.

\section{The Fantasy of the Heroic Entrepreneur}

Echoing Žižek (2008 [1989]), Jones and Spicer (2005) contend that entrepreneurship constitutes a sublime object. Žižek defines a sublime object as 'a positive, material object elevated to the status of the impossible Thing' (2008: 77). At a distance, the sublime object appears to possess divine and extraordinary qualities. But once directly encountered, the sublime object loses its aura and dissolves into an ordinary thing, because its seductive appearance can be sustained only through distance. 'If we get too near [the sublime object]', Žižek explains, then 'it loses its 
sublime features and becomes an ordinary vulgar object' (2008: 192). Jones and Spicer suggest that famous entrepreneurs are paradigmatic examples of sublime objects. The public image of Microsoft founder Bill Gates, for instance, tends to elevate him to a 'heroic status as if there is something unique to his psyche that is the ultimate cause of his economic success' (Jones and Spicer, 2005: 237). But if we had the chance of actually meeting Gates in person, Jones and Spicer speculate, then we would 'find that Bill Gates is just an ordinary human being with perfectly normal and human neuroticism' (2005: 237).

It is important here, however, not to underestimate the persuasiveness of entrepreneurs and the grasp that sublime objects have on us. As a matter of fact, most of us never have the opportunity to meet famous entrepreneurs in person. And if we do, we are often placed at a distance that keeps us from getting close to them. Instead, we read about famous entrepreneurs in newspapers and see their portraits on television. Such distance effectually preserves the sublime aura surrounding entrepreneurs. Rarely do we encounter instances in which the sublime object of entrepreneurship is completely dispelled, although it might take place. Jones and Spicer are acutely aware that the sublime features of entrepreneurs are rarely relinquished, so they emphasize that the 'entrepreneurship discourse clearly does exist' and that it 'offers a narrative structure to the fantasy that coordinates desire' (2005: 237). The role of fantasy, according to Žižek, would thus be 'an attempt to overcome, to conceal this inconsistency, this gap in the Other' (2008: 139).

Kenny and Scriver maintain that 'as an "empty" signifier [entrepreneurship] can be (almost) whatever one desires it to be' (2012: 617). We would suggest, instead, that we reverse this formula: The figure of the heroic entrepreneur is not an empty shell that can be manipulated through desire, but rather a fantasy that 'coordinate[s] desire' (Kosmala, 2013: 4). Viewed from this perspective, narratives about famous and successful entrepreneurs circulating in popular culture and social media may reveal the fantasies constituting their desire to become entrepreneurial. In this way, Žižek (2008) reverses the way that we normally regard the relationship between desire and fantasy. The role of fantasy is not to image the realization of desires that we cannot fulfil in reality, but rather to make us capable of desiring in the first place. In Žižek’s words: 
fantasy does not mean that, when I desire a strawberry cake and cannot get it in reality, I fantasize about eating it; the problem is, rather, how do I know that I desire a strawberry cake in the first place? This is what fantasy tells me (Žižek, 2006a: 40).

For Žižek, the problem lies in the constitution of desire. We therefore need to pose the question: Why do we desire certain things? How do fantasies form desires? Here desire signifies the way in which we long for, crave and feel a need for certain objects, such as fame, fortune and glory. In order to desire even a mundane object like a 'strawberry cake', Žižek elaborates, 'every subject has to invent a fantasy of his own' (2006a: 41). As such, a fantasy is a narrative that renders certain objects attractive for us. Put differently, fantasies reside in the narratives we tell, insofar as they render certain things desirable. Hence, fantasies do not stem from nowhere. Quite the opposite, Žižek believes that we inherit fantasies from the symbolic structures that surround us. In this way, desire is mimetic, according to Žižek. To illustrate this point, Žižek cites the Lacanian formula: 'man's desire is the Other's desire' (2006b: 42). In other words, we learn to desire by subscribing to the fantasies that circulate in the symbolic structures permeating society. In this way, Žižek allow us to read Branson's autobiography as a symbolic structure that creates fantasies that the reader can adopt. These fantasies, in turn, serve to create desire by making certain objects attractive.

Žižek's reversal of the conventional relationship between desire and fantasy allows us to address the question of 'Who is an entrepreneur?' without recourse to an essentialist mode of thinking. If we adopt Žižek’s approach, reading Branson's autobiography enables us to explore how the figure of the heroic entrepreneur emerges as a fantasy in the book that structures desire.

According to Žižek (2008), fantasy should not be equated with what we normally associate with illusory and false perceptions, because it provides the necessary support for us to relate to social reality, enabling each subject to desire objects. Thus, fantasy is not a false mirage without which we would see the world much clearer. The point, therefore, is not to dismiss Branson's autobiography as a fantasy as opposed to actual reality. Instead, Žižek's (2006a) formulation of fantasy enables us to read Branson's autobiography as a literary instruction that teaches us how to desire, as we attend to the injunction it creates. However, fantasies are never complete, but 
always marked by impossibility (Jones and Spicer, 2005). Inspired by Žižek, the analytic challenge consists of exploring how Branson's autobiography generates fantasies that structure desire while simultaneously discovering at how these fantasies are ridden with impossibilities and contradictions.

\section{Traversing the Fantasy of Richard Branson}

Before turning to his autobiography Losing My Virginity, it is important to note that several unauthorized biographies of Branson have been published in past decades, including Bower's two books Branson (2000) and Branson: Behind the Mask (2014) and Jackson's Virgin King (1998). What these unauthorized biographies share in common is their tendency to reveal the dark secrets behind the popular perception of Branson. Informed by Bower (2000) and Jackson (1998), Armstrong (2005: 88) argues that while Branson is widely celebrated as 'the iconic entrepreneur of our times', the reality behind Branson's success is anything but admirable. Rather than being viewed as the driver of innovation at Virgin, Armstrong (2005) claims that Branson would be better characterized as a 'parasite' on the creative people associated with the company. Branson's ability to manipulate people enabled him to gain control of the company and thereby cash out the profit from what had actually been generated by a collective effort. For Armstrong, Branson's public image is therefore an ideological construct - in the classical

Marxian sense - that effectually distorts the actual social circumstances that have made Virgin a multinational corporation. In effect, Armstrong argues that 'the mode of entrepreneurship outlined here [through analysing Branson], is not the Schumpeterian engine of innovation at the heart of the capitalist economy, but a social and economic pathology to which that economy is chronically vulnerable’ (2005: 103).

Although the critical strategy of unmasking has proved to be a fruitful way for debunking the fantasy of the heroic entrepreneur, we will adopt a different approach. Instead of looking at the reality behind the fantasy of Branson, we propose to confront the fantasy itself. While Bower suggests in his recent biography that the 'challenge is to discover the truth behind the mask' of Branson (2014: xvi), we want to call into question the mask on its own merits. To do so, we will take Branson's autobiography Losing My Virginity at face value and inquire into the fantasies 
that it creates. Our goal here is not simply to affirm the fantasies enacted by Branson's autobiography. On the contrary, we want to expose the impossibilities and contradictions embedded in them. The point is not to dismiss the critical strategy of demasking altogether. Rather, the point is that we want to find the crack within the mask itself instead of looking at the reality behind the mask. So 'demasking' for us consists of unveiling the rift that resides within the mask presented in Branson's autobiography. In other words, we want to disclose the deceptive surface of Branson's narrative by exploring the contradictions and impossibilities it produces. In Nietzsche's words, the challenge 'is to stop bravely at the surface' (2001: 8), since we are only able to 'discover depth after conquering the surfaces' (Deleuze, 1990: 147; for discussion, see Sørensen, 2013).

Instead of unmasking the phantasmic narratives that we regularly encounter in social media with the intention to 'liberate us from the hold of idiosyncratic fantasies and enable us to confront reality the way it is', Žižek (2012: 689) proposes the opposite strategy: To fully equate the fantasy with reality and then spell out all the radical implications that follow. This critical strategy is what Žižek calls 'traversing the fantasy' which basically 'means, paradoxically, to fully identify oneself with the fantasy - with the fantasy which structures the excess that resists our immersion in daily reality’ (2012: 689). Murtola refers to this approach as overidentification: something is 'exaggerated ad absurdum in an attempt to break the apparent natural order as it comes to expression under capitalism' (2012: 327, emphasis in original). The point of undertaking such a reading of Branson is to confront the fantasy as such rather than eschewing it. Considering the biographies that have questioned Branson's personal account, such an approach may seem unreasonable. But this is precisely the point. As De Cock and Böhm argue, a 'Žižekian reading of popular management discourse would by definition be "unreasonable"; it would fully assume the tenets of the discourse and push these to the point of their absurdity' (2007: 828). This is what we will do now.

\section{Richard Branson's Losing My Virginity}

In broad strokes, Branson's autobiography tells the story of how he managed to transform a student magazine into a global business empire while simultaneously engaging in various 
attempts to break records, such as flying a hot air balloon across the Pacific or reclaiming the blue ribbon for fastest ferry across the Atlantic. While being a businessman and doing extreme sports may seem vastly different, for Branson, these activities actually followed the same logic, since they posed challenges that he was driven to overcome. The book, which is structured chronologically, oscillates between telling anecdotes about how Branson managed to turn Virgin from a mail order service to a global company and reporting the details of his extravagant lifestyle, hanging out with celebrities, vacationing at his private island in the Caribbean, speed boating and flying hot-air balloons. Thus, the book is not a narrative as such, but more a series of narratives about Branson's life, such as his attempt to fly around the world in a balloon and his decision to sign Mike Oldfield which marked the breakthrough of the record company Virgin. Taken together, these stories paint a picture of Branson as an entrepreneur who constantly seeks new challenges by testing the limit of what is possible as a risk-taking sportsman, while also striving to manage his company in hard times.

In what follows, we will focus on two anecdotes from the book. The first tells about Branson's childhood memory of learning to swim, while the second is about a tax scam that he orchestrated to save Virgin at an early stage of its development. These stories have been chosen because they nicely illustrate what we consider the general logic of Branson's narrative, which is constituted by the desire for transgression (overcoming oneself) and the desire for authenticity (becoming oneself). Thus, we consider these two anecdotes to highlight certain logics of desire that permeates Branson's narrative and that constitute the entrepreneurial subjectivity presented in the book. As such, the two narratives operate as fantasies, since they render certain ideals - that is, transgression and authenticity - desirable. We are aware that other stories could have been chosen and that a different theoretical framework could have been employed in the analysis. But instead of providing a comprehensive reading of Branson autobiography that deals with all aspects of his narrative, we will concentrate on two anecdotes in order to gain a deep understanding of the logics of desire they generate. The first anecdote has therefore been chosen because it illustrates Branson's constant effort to overcome himself while the second anecdote has been chosen because it illustrates his struggle to remain true to himself. 
Taken together, the desire for transgression (overcoming oneself) and the desire for authenticity (becoming oneself) make up the entrepreneurial subjectivity presented in Branson's autobiography. In other words, the figure of the entrepreneur emerges in the book as the one who is able to achieve transgression and authenticity. Although the book is an autobiography, it should be read in relation to Branson's other books that are explicitly aimed, as he states in one of their subtitles, at revealing the 'secrets they won't teach you at business school' (2012). These books make use of many of the same stories that are told in Branson's autobiography but turn them into explicit lessons that the reader should follow in order to become a successful entrepreneur. As Branson states, entrepreneurship is 'the core of everything that I have done for the last forty-plus years' (2012: 2). Instead of challenging such claims, we will fully accept that this is the case and inquire into what they reveal about his entrepreneurial subjectivity.

\section{Learning to Swim: The Desire for Transgression}

In his seminal work on entrepreneurship, Schumpeter talked about the entrepreneur as someone who is 'swimming against the stream' (cited in Boje and Smith, 2010: 308). While Schumpeter clearly saw this only as an apt metaphor, the distance between the metaphor and actual practice is perhaps small; one of the most significant memories Branson recounts from his childhood is precisely his experience of learning to swim. Around the age of four or five, little Richard made a bet of ten shillings with his aunt Joyce that he could learn to swim within two weeks. At this time, Richard was spending his holidays with his aunt and uncle in Devon, approximately a twelve-hour drive from his home. Despite countless efforts, the boy was unable to coordinate his

body and learn the right technique. Branson recalls that he 'spent hours in the sea trying to swim against the freezing-cold waves, but by the last day I still couldn't do it' (2009: 16). Every attempt ended up with him being dragged beneath the surface and swallowing water. At the end of the vacation, Richard's parents came to drive him home. He had still not learned to swim, but his aunt reassured him that the bet was still on for next year. As Richard drove home with his parents and his two aunts, he spotted a river along the road.

'Daddy, can you stop the car, please?' I said. 
This river was my last chance: I was sure that I could swim and win Auntie Joyce's ten shillings.

'Please stop!' I shouted.

Dad looked in the rear-view mirror, slowed down and pulled up on the grass verge. 'What's the matter?' Aunt Wendy asked, as we all piled out of the car.

'Ricky's seen the river down there,' Mum said. 'He wants to have a final go at swimming.'

(ibid.: 16-17)

Richard's father agreed to stop the car, so the boy could get a final chance to prove his ability to swim. While the river must have looked calm from the distance, it proved to have a strong current. Yet, Richard was determined to show that he could swim, even if it meant crossing the dangerous stream.

I pulled off my clothes and ran down to the riverbank in my underpants. I didn't dare stop in case anyone changed their mind. By the time I reached the water's edge I was rather frightened. Out in the middle of the river, the water was flowing fast with a stream of bubbles dancing over the boulders. [...] I looked back. [...] Dad was lighting his pipe and looking utterly unconcerned; Mum was smiling her usual encouragement (ibid.: 17).

At first, the he struggled to swim, as he had done so many times before. But he was determined to cross the river. 'I had to win that ten shillings' (ibid.).

I braced myself and jumped forward against the current, but I immediately felt myself sinking, my legs slicing uselessly through the water. The current pushed me around, tore at my underpants and dragged me downstream. I couldn't breathe and I swallowed water. [...] Then my foot found a stone and I pushed hard. I came back above the surface and took a deep breath. The breath steadied me, and I relaxed. I had to win that ten shilling. I kicked slowly, spread my arms, and found myself swimming across the surface. I was still bobbling up and down, but suddenly felt released: I could swim (ibid.). 
On the surface, Branson explicitly proclaims in one of his books, entitled Screw It, Let's Do It: Lessons In Life, that it is important to 'have faith in yourself', 'believe it can be done' and 'never give up' (Branson, 2006: 1). These imperatives resonate nicely with Branson's childhood memory of learning to swim. Despite repeated failures, he retained his faith in himself, believed that he could learn to swim and never gave up. Eventually, Branson succeeded. But this story actually conveys a much stronger message. As the story makes clear, Branson is not a naturally talented swimmer. On the contrary, he struggled immensely to win the bet. Moreover, he experienced fear once he stepped into the river. Despite these challenges, he remained determined to learn to swim. Branson's physical dispositions and psychological inclinations are barriers that he has to overcome in order to succeed. Read as a fantasy, the story describes a subject that desires transgression in the sense of overcoming barriers that hinder self-realization.

Normally, transgression refers to the violation of a norm or law. But here we use the concept of transgression to denote the way in which the entrepreneur must exceed the boundaries and limits restricting his or her scope of action. Thus, transgression consists of overcoming those barriers that are believed to restrain one's ability to think and act. For example, Branson explains that he suffers from dyslexia, a condition that was considered a sign of either stupidity or laziness at the time he was growing up (2009: 31). However, Branson did not avoid situations where he was exposed to his lack of skills in writing and spelling. Quite the opposite, Branson voluntarily signed up for an essay competition that he eventually won, and he subsequently founded a student magazine that he later developed into his first commercial business. Following this fantasy, the heroic entrepreneur reminds us: Not only should you have faith in yourself, you should have faith that you can overcome your limitations. Not only should you believe that it can be done, you should believe that everything can be done. And not only should you never give up, you should be willing to sacrifice everything, even if it involves risking your life, in order to ensure that you succeed.

It is difficult not to recognize the 'metaphysical subtleties and theological niceties' (Marx, 1995: 42) embedded in this narrative. Like Goethe's self-expanding and limit-defying Faust, Branson recognizes no obstacles for his agentive progress, not even the sacrifice of that very agentive self (Sørensen, 2008). Specifically, the entrepreneur should be devoted to 'progress forever' and 
strive for an eternal "liberation from the chains of the world "as it is"' (Gehmann, 2003: 96). Clearly, the desire for transgression is radically different from the conventional wisdom expressed by Drucker that you should 'improve your strengths' while evading your 'weaknesses' (2005). Rather, the underlying message in Branson's story is that you should turn your weaknesses into strengths. The entrepreneurial subject projected in Branson's autobiography is an 'entrepreneur of the self' (du Gay, 1994) that is expected to be continuously 'transcending social constraints' (Sköld, 2010: 371) and to overcome his/her own limits. The entrepreneur should not only challenge the prevalent assumptions of the organization but also constantly challenge him- or herself. The desire for transgression is therefore the entrepreneurial subject's prime driver.

As Žižek notices, 'permanent transgression already is a key feature of late capitalism' (2012: 332-333). The entrepreneurial subject engages in a continuous 'transgression and destruction of boundaries' that, in turn, generate 'a new bond between economic grammars of production and consumption, and cultural grammars of the modern self' (Costea et al., 2005: 141). However, there is a fundamental impossibility that resides within the desire for transgression. This impasse stems from the paradox of perpetually pushing limits. As Branson explains, his 'interest in life comes from setting myself huge, apparently unachievable, challenges and striving to raise above them' (2009: 194). Apparently, it does not fundamentally matter for Branson whether these challenges are swimming across a river, launching a new business or flying an air balloon. What is important is to transgress boundaries. By doing so, Branson seeks to 'live life to the full' (2009: 194). But one can never completely achieve a full life according to this logic, because there are always new challenges that have not yet been accomplished. Branson wants to 'push myself to my limits' (2009: 212). Limits are but hindrances that have not yet been transgressed. As he puts it: 'I firmly believe that anything is possible' (Branson, 2009: 258).

But if anything is possible, then it is impossible to live a full life because there is no limit against which one can reach wholeness. Only that which is finite can be complete. Everything else remains potentially open. At age forty, Branson faced a crisis because he lacked motivation for new challenges. Having turned Virgin into a successful business and crossed the Pacific by air balloon, he felt that he had 'run out of purpose in my life', having 'proved myself to myself in 
many areas' (Branson, 2009: 293). Failure to have any boundaries that one wants to transgress is therefore a constant threat. Every time 'we feel sure that we have fulfilled a desire, we find out that there is something missing still. We want more. We want something else' (Driver, 2009: 410). His escape from this impasse was to organize for a Virgin plane to travel to Baghdad in the midst of the first Gulf war to rescue hostages in return for medical supplies. This enabled Branson to find a new spark of life, as he entered a territory of challenges that he had never encountered before. However, this story also bears witness to the paradoxical fact that achieving a full life can only be accomplished by living a life that always remains incomplete, as one is exposed to tasks that seems unachievable and must overcome further obstacles that challenge one's abilities.

Consequently, Branson seeks fullness through transgression, yet he is intrinsically unable to achieve finitude. The problem is that the "realization of desire does not consist in its being "fulfilled", "fully satisfied", it coincides rather with the reproduction of desire as such, with its circular movement' (Žižek, 2009: 7). What drives the desire for transgression is precisely the impossibility of finitude. There is only one limit: death. As Branson remarks ironically, 'death and taxes are the only sure-fire things in life' (2009: 137). At the same time, 'death' is always the very limit that Branson engages with and throws himself upon, even while formally recognizing its character as absolute. But even if death (and taxes) remain sure-fire things, facing the ultimate opponent (death for a human, the State's taxation for an entrepreneur) is what the entrepreneur must seek to transgress. His attempt at learning to swim was only a preamble for a series of neardeath exercises, involving gravity-defying Himalayan adventures, skydiving and air ballooning. Richard Branson is clearly engaged in a metaphysical struggle against any ultimate limit. Here a metaphysical narrative is invoked in which death is not a limit, but actually the final sublime experience, an experience that eventually will set Branson (the entrepreneur) apart from the average reader (the wage labourer). In St. Paul's version of this narrative, to live is to be filled with a radically other engagement (namely Christ) and 'to die is gain' (Phil. 1:21).

\section{The Tax Scam: The Desire for Authenticity}


In the 1960s, Branson went from being editor of the magazine Student to selling records by mail. The company was called Virgin Mail Order, a name invented by one of the female employees at Student magazine to signal that they were 'completely virgins at business' (Branson, 2009: 77). At first, the business was successful. But in the spring of 1971, the business started recording deficits. Branson recalls that 'all in all we were gradually losing money, and before long we were $£ 15,000$ overdrawn' (ibid.: 92). On one occasion, Branson received a large record order from a client in Belgium. He decided to load a van with records and deliver the order himself. Because the records were not intended for sale in the UK, Branson was allowed to buy the records from the publishers without paying tax.

At the French border, however, the authorities demanded that Branson should pay import tax on the records. In effect, Branson was forced to return to the UK without being able to deliver the order to Belgium. When he arrived in the UK, however, Branson realized that he could now sell the records without having paid purchase tax on them. In effect, Branson could 'make about $£ 5,000$ more profit than I could have done by legal route’ (ibid.: 93). By coincidence, Branson had discovered a way to get Virgin out of debt. Branson was well aware that he was breaking the law. But he decided to keep avoiding purchase tax until he had raised enough money to pay all of Virgin's outstanding bills. Besides, Branson was accustomed to bending the rules to achieve his objectives. He explains that: 'It was a criminal plan, and I was breaking the law. But I had always got away with breaking the laws before' (ibid.: 93). Not surprisingly, Branson was not the only one who had conceived such a plan,, and before long, British tax authorities were investigating Virgin. One day the Customs and Excise officials raided Virgin's stores, and Branson was arrested.

I couldn't believe it. I had always thought that only criminals were arrested: it hadn't occurred to me that I had become one. I had been stealing money from Customs and Excise. It wasn't some great game about me getting one up on the Customs and Excise office and getting off scot-free: I was guilty (Branson, 2009: 99-100).

Branson had to spend the night in prison. As he was lying in his bed in his prison cell, Branson had a revelation that he describes in the following manner: 
That night was one of the best things that has ever happened to me. As I lay in the cell and stared at the ceiling I felt complete claustrophobia. I have never enjoyed being accountable to anyone else or not being in control of my own destiny. I have always enjoyed breaking the rules [...] But to be in prison meant that all that freedom was taken away (ibid: 100).

As Branson realized, breaking the law ended up depriving him of his freedom. With this insight, Branson 'vowed to myself that I would never again do anything that would cause me to be imprisoned' (ibid.: 100). Branson’s bail was set at $£ 30,000$. But the company did not have any money. Instead, Branson's mother decided to mortgage her house to pay the authorities. When Branson met his mother outside court, they both started crying.

'You don't have to apologise, Ricky,' Mum said as we took the train back up to London. 'I know that you've learnt a lesson. Don't cry over spilt milk: we've got to get on and deal with this head on' (ibid.: 101).

What Branson realized in the prison cell was that he "needed to work twice as hard to make Virgin a success' (ibid.: 102). This was not just related to the fine he had to pay to Customs and Excise. It was an entire ethos of work that had become embedded in him to such an extent that he finally states: 'avoiding prison was the most persuasive incentive I've ever had' (ibid.: 102). By learning this lesson, the same lesson his mother cites, Branson turned the moment of claustrophobia in the prison cell into 'one of the best things that has ever happened to me' (ibid.: 100). To redeem the wrongs that he had committed, risking the whole company and placing his family in debt, Branson swore an oath in his prison cell. Since he was isolated from his social surroundings in the prison cell, he did not make the promise to his family or his company. Instead, Branson swore an oath to himself, taking on the commitment to abide by the law as a self-reflexive relationship that would serve to maintain authenticity. He had become a new person. He was a convert. 
Branson's earlier story conveyed the desire to continuously transgress boundaries. Unlike the desire for transgression, the second story operates according to a different logic of desire. Rather than challenging himself, Branson makes the promise to remain 'true to [him]self' (Garsten and Grey, 1997: 222) by staying committed to the oath he had sworn never to break the law. The theological references here are again evident insofar as Branson's narrative 'transfers enchantment [the mystical nightly visionary experience] from a religious context towards a secular, economic context' (Sørensen et al., 2012: 271). The prison cell comes to resemble a monastic cell. In Czarist Russia during the Middle Ages, opponents were often incarcerated in prisons within Orthodox monasteries (Shubin, 2001). For Branson, in his prison/monastery cell, lying at night staring at the ceiling becomes an epiphany in which he is called to repay for the rest of his life the guilt acquired through the import tax scam. In a Weberian sense, Branson commits to an apparently secularized work ethic, an ethic of penitence that requires him to repay his debt through hard work. In this way, the night in prison accommodates a conversion from a previous sinful self towards an authentic being (for a discussion of conversion and entrepreneurship, see Sørensen, 2010).

As we can see, the story resonates with a more general desire for authenticity, offering 'access to an inner moral voice of conscience, an intuitive feeling or sentiment that gives us moral guidance as to how we should act' (Guignon, 2008: 278). Insight into one's 'inner voice' (Garsten and Grey, 1997: 225), triggered by the experience of claustrophobia in the prison cell, becomes the hallmark of how 'true' one is to the 'self' one has propagated (Johnsen, 2015). Branson realizes that he has to assume responsibility for staying in 'control of [his] own destiny' (2009: 100). Here ethics is grounded neither in social relations nor bureaucratic regulations, but rather in personal responsibility (De Cock and Böhm, 2007). The imperative of authenticity is premised on continuous self-examination and self-evaluation, a fact that opens the self to become the site for interventions and local tactics. As with Branson's promise to abide by the law, 'integrity of the self comes from creating a personal belief system' (Garsten and Grey, 1997: 223).

One might suspect here that there is a contradiction between the desire for transgression and desire for authenticity, since the latter requires that you remain true to yourself while the former requires that you overcome yourself. However, this contradiction can be resolved by considering 
the injunction to transgress oneself as necessary in order to overcome the inauthentic self and henceforth reach a new authentic being. Such a solution resonates with the central Christian formula found in Paul's letters that focus on 'the new self who is being renewed to a true knowledge according to the image of the One who created him' (Col. 3: 10-11). For Paul, transgression is the road to redemption, since only by overcoming yourself is it possible to attain authenticity (Sørensen, 2008). This logic is reflected in the way in which Branson constructs a phantasmagorical narrative of a 'new self' that, through the painful dark night of his soul experienced in the cell, has transgressed his previous (sinful) behaviour and has come to partake (gracefully) in entrepreneurial creation.

Although the two anecdotes that we have discussed here share many similarities, there are also some important differences. While the first story of learning to swim, a rite of passage for any child, was structured as a success narrative, the story of the tax scam marks a failure, since Branson ends up in prison. Thus, he fails to pull off the tax scheme in order to save his company. However, this failure is immediately converted by Branson into a productive lesson, a learning experience, because he commits himself to the task of redeeming his failure. For Branson, his 'night [in prison] was one of the best things that ... ever happened' (2009: 100). Here the figure of the entrepreneur emerges as a redeemer who sacrifices himself for the sake of the company (Sørensen, 2008). The entrepreneur comes to emulate the transformative leader who must be prepared to make the ultimate sacrifice - in the famous case of the Chrysler CEO Lee Iaccoca, the sacrifice of his entire salary - in order to change the world (see Sliwa et al., 2013). Yet, of course and contrary to Christianity, if you fail as an entrepreneur, there is no escape: capitalism remains, in Benjamin's (1996) icy formulation, historically the first cult practiced without the notion of redemption.

\section{Discussion}

Hjorth et al. claim that 'new concepts of entrepreneurship enable us to think differently and practice the world differently' (2008: 82). With the help of Žižek's concept of 'fantasy' and his strategy of 'traversing the fantasy', we have attempted to show how it is possible to engage with the figure of the heroic entrepreneur without assuming an essentialist mode of thinking. This 
approach does not seek to 'unmask' the entrepreneur by looking at the reality behind the mask, but rather explores the nature of the mask itself. But what we can learn from 'traversing the fantasy' of Branson's narrative is that the figure of the heroic entrepreneur is not just someone who embodies extraordinary qualities. This figure is also ridden with paradoxes, impossibilities and contradictions. We do not have to look beneath or beyond the figure of the heroic entrepreneur in order to unmask or disclose 'the "dark side" of the entrepreneurship phenomena' (Verduijn et al., 2014: 99), since we can see, following Tedmanson et al., that these 'dark' aspects, including 'contradictions, paradoxes, ambiguities and tensions', reside 'at the heart of entrepreneurship' (2012: 532). Thus, we can begin to see that what we encounter in the figure of the heroic entrepreneur circulating in social media and popular culture is not a flawless and sublime character, but rather a fragile and vulnerable construct.

Reading Branson's autobiography has allowed us to locate two fantasies created by the figure of the heroic entrepreneur. According to the fantasy of transgression, the entrepreneur must continuously seek to transgress boundaries. Such boundaries are potential obstacles that must be overcome. Yet, the fantasy of transgression is then supplemented by a paradoxical fantasy, that of authenticity. According to this fantasy, the entrepreneurial subject seeks to remain within the confines of the true self and stay loyal to its intentions. In this fantasy, the figure of the entrepreneur considers the true self to be an inner moral voice that provides the basis for ethical behaviour. As a result of this, the entrepreneurial subject is caught between the desire to overcome oneself (transgression) and the desire to stay true to oneself (authenticity). In this light, the heroic figure of the entrepreneur dwells in a crisis that results from being constituted across contradictory structures of desire.

One might consider the impossibility of overcoming oneself (transgression) and becoming oneself (authenticity) as holding back the actualization of the entrepreneur. Following this line of argument, becoming a successful entrepreneur, as described in Branson's narrative, can take place only after one has simultaneously overcome oneself (transgression) and become oneself (authenticity). With Žižek, however, we can turn this relationship upside down. Rather than obstructing the actualization of the entrepreneur, it is the impossibility of transgression and authenticity that fuels the desire for entrepreneurship. To put it in slightly different terms, the 
impossibilities inherent in the figure of the entrepreneur are precisely what make the figure appealing.

We should not take for granted that the figure of the heroic entrepreneur is a normative ideal that would necessarily be preferable to attain. It is not a perfectly designed 'mask' with which we can harmoniously identify. Quite the opposite, it is a contradictory and impossible frame, recognizable primarily as another failed attempt to construe subjectivity. What makes the figure of the heroic entrepreneur appealing and widespread is its fragile, incomplete and overall vulnerable character. According to Žižek, the fantasy haunting the modern subject is not that we are estranged and alienated from our true selves, but on the contrary, that there is a 'real self' hidden beneath our 'phantasmic identities' (Žižek, 2009: 330). Stripped of its phantasmic support, the subject is only a void marked by a lack. For Žižek, the search for a 'true self' can only result in an 'identity crisis', because what the subject will find once it is isolated from its social surroundings is nothing but a 'void of idiocy pure and simple' (2009: 373).

At one level, the contradictions and impossibilities in Branson's autobiography imply that we cannot completely identify with the fantasies it creates. Obviously, we cannot simply become 'Sir Richard Branson' by reading this autobiography. But beyond this, by traversing the fantasies that we encounter in Branson's narrative, we discover the uncanny fact that just as we clearly cannot become the hero of this narrative, it is also impossible for Sir Richard Branson to become that figure. Branson cannot be himself; he is a stranger even to himself. And here lies his appeal: it is exactly because he expresses incompleteness and paradox as an inevitable human condition that he is attractive. What we see in Branson's narrative is not a false image, but rather the same impossibility that we recognize in our own being. This is why we, the average reader, can somehow identify with the billionaire skydiver with a private island. What we encounter in the other, such as Branson, 'is not his or her spatial exteriority with respect to my being but the fact that he or she is strange, is a stranger; and not only to me but to him - or herself, is the bearer of an internal alterity' (Santner, 2001: 9, original italics; see also Kristeva, 1994).

\section{Conclusion}


While considerable critical energy has been devoted to unmasking the figure of the heroic entrepreneur, the idea that entrepreneurs are unique individuals with special abilities seems remarkably resilient. The unique, heroic entrepreneur - even as the asocial nerd in the garage continues to be widespread in social media and popular culture. In this paper, we have confronted the figure of the heroic entrepreneur by drawing on Žižek's idea of 'traversing the fantasy'. Rather than striving towards a processual approach that lays emphasis on the collective effort involved in entrepreneurship, we have engaged with the fantasy of the individual entrepreneur by disclosing how this figure structures desire. To do so, we have offered a reading of Richard Branson's autobiography Losing My Virginity, which serves to illustrate how the fantasy of the heroic entrepreneur creates the injunction to transgress oneself and therefore become true to oneself, but also how this figure is ridden with contradictions and paradoxes. It is precisely these contradictions and paradoxes, the unfinished nature of the self, that make the heroic entrepreneur figure appealing, and which explains why an effort to damask the entrepreneur, to turn them into one of us, does not diminish its effect. Our reading has sought to show how critical entrepreneurship studies could benefit from an approach that looks critically at how the cultural representation of business today thrives on rebellious narratives and celebrates the heroic entrepreneur as a source of value-creation. Yet, it is precisely the same impossibilities that we struggle with, and which makes his narrative appealing to the reader.

\section{References}

Ahl, H. (2006), "Why research on women entrepreneurs needs new directions", Entrepreneurship Theory and Practice, Vol. 30 No. 5, pp. 595-621.

Alvarez, S.A. and Barney, J.B. (2007), "Discovery and creation: alternative theories of entrepreneurial action”, Strategic Entrepreneurship Journal, Vol. 1 No. 1-2, pp. 11-26. Armstrong, P. (2001), "Science, enterprise and profit: ideology in the knowledge-driven economy", Economy and Society, Vol. 30, No. 4, pp. 524-552.

Armstrong, P. (2005), Critique of Entrepreneurship: People and Policy, Palgrave Macmillan, Houndmills, Basingstoke, Hampshire and New York.

Benjamin, W. (1996), “Capitalism as Religion” Selected Writings, W., Bullock, M. P. \& Jennings, M. W. (eds.). Cambridge, Mass.: Belknap Press of Harvard Univ. Press, pp. 288-291. 
Boje, D. and Smith, R. (2010), "Re-storying and visualizing the changing entrepreneurial identities of Bill Gates and Richard Branson", Culture and Organization, Vol. 16 No. 4, pp. $307-331$.

Bower, T. (2000), Branson, Harper Perennial, London.

Bower, T. (2014), Branson - Behind the Mask. Faber, London.

Branson, R. (2006), Screw It, Let's Do It: Lessons in Life, Virgin Books, London.

Branson, R. (2009), Losing My Virginity: The Autobiography, Virgin Books, London.

Branson, R. (2012), Like a Virgin: Secrets They Won't Teach You at Business School, Portfolio Trade, New York.

Brockhaus, R.H. (1980), "Risk-taking propensity of entrepreneurs", Academy of Management Journal, Vol. 23 No. 3, pp. 509-520.

Bull, I. and Willard, G.E. (1993), "Towards a theory of entrepreneurship", Journal of Business Venturing, Vol. 8 No. 3, pp. 183-195.

Burns, P. (2001), Entrepreneurship and Small Business, Palgrave, Houndmills, Basingstoke, Hampshire; New York.

Calas, M.B., Smircich, L. and Bourne, K.A. (2009), "Extending the boundaries: reframing 'entrepreneurship as social change' through feminist perspectives", Academy of Management Review, Vol. 34, No. 3, pp. 552-569.

Cornelissen, J.P. (2013), "Portrait of an Entrepreneur: Vincent van Gogh, Steve Jobs, and the Entrepreneurial Imagination”, Academy of Management Review, Vol. 38 No. 4, pp. 700-709. Costa, A. de S.M. da and Saraiva, L.A.S. (2012), "Hegemonic discourses on entrepreneurship as an ideological mechanism for the reproduction of capital", Organization, Vol. 19 No. 5, pp. 587614.

Costea, B., Crump, N. and Holm, J. (2005), "Dionysus at work? The ethos of play and the ethos of management", Culture and Organization, Vol. 11 No. 2, pp. 139-151.

De Cock, C. and Böhm, S. (2007), "Liberalist fantasies: Žižek and the impossibility of the open society", Organization, Vol. 14 No. 6, pp. 815-836.

Deleuze, G. (1990), The Logic of Sense, New York: Columbia University Press.

Down, S. (2006), Narratives of Enterprise: Crafting Entrepreneurial Self-Identity in a Small Firm, Edward Elgar, Cheltenham, UK; Northampton, MA. 
Down, S. (2013), “The distinctiveness of the European tradition in entrepreneurship research”, Entrepreneurship \& Regional Development, Vol. 25 No. 1-2, pp. 1-4.

Downing, S. (2005), "The social construction of entrepreneurship: narrative and dramatic processes in the coproduction of organizations and identities", Entrepreneurship Theory and Practice, Vol. 29 No. 2, pp. 185-204.

Drakopoulou Dodd, S. and Anderson, A.R. (2007), "Mumpsimus and the mything of the individualistic entrepreneur", International Small Business Journal, Vol. 25 No. 4, pp. 341-360. Driver, M. (2009), "Struggling with lack: A Lacanian perspective on organizational identity", Organization Studies, Vol. 30 No. 1, pp. 55-72.

Drucker, P.F. (2005), “Managing oneself”, Harvard Business Review, Vol. 100, pp. 8017-8012. du Gay, P. (1994), "Making up managers: bureaucracy, enterprise and the liberal art of separation”, The British Journal of Sociology, Vol. 45 No. 4, pp. 655-674.

Fleming, P., and Spicer, A. (2005) 'How objects believe for us: applications in organizational analysis', Culture \& Organization, Vol. 11 No. 3, pp. 181-193.

Garsten, C. and Grey, C. (1997), "How to become oneself: discourses of subjectivity in postbureaucratic organizations”, Organization, Vol. 4 No. 2, pp. 211-228.

Gartner, W.B. (1988), "Who is the entrepreneur? is the wrong question", American Journal of Small Business, Vol. 12, pp. 11-32.

Gartner, W.B. (2007), "Entrepreneurial narrative and a science of the imagination”, Journal of Business Venturing, Vol. 22 No. 5, pp. 613-627.

Gartner, W.B. (2013), “Creating a community of difference in entrepreneurship scholarship”, Entrepreneurship \& Regional Development, Vol. 25 No. 1-2, pp. 5-15.

Gehmann, U. (2003). "Prometheus", ephemera. theory and politics in organization, Vol. 3 No. 2, pp. 95-114.

Guignon, C. (2008), “Authenticity”, Philosophy Compass, Vol. 3 No. 2, pp. 277-290.

Hjorth, D. (2007), “Lessons from Iago: Narrating the event of Entrepreneurship", Journal of Business Venturing, Vol. 22 No. 5, pp. 712-732.

Hjorth, D. and Steyaert, C. (2004), Narrative and Discursive Approaches in Entrepreneurship: A Second Movements in Entrepreneurship Book, E. Elgar Pub., Cheltenham, UK; Northampton, MA. 
Hjorth, D., Holt, R. and Steyaert, C. (2015), "Entrepreneurship and process studies", International Small Business Journal, Vol. 33 No. 6, pp. 599-611.

Hjorth, D., Jones, C. and Gartner, W.B. (2008), "Introduction for 'Recreating/Recontextualising Entrepreneurship"”, Scandinavian Journal of Management, Vol. 24 No. 2, pp. 81-84.

Jackson, T. (1998), Richard Branson, Virgin King: Inside Richard Branson's Business Empire, Prima Pub., Rocklin, CA.

Johnsen, C. G. (2015), “Authenticating the Leader: Why Bill George Believes that a Moral Compass Would Have Kept Jeffrey Skilling out of Jail”, Journal of Business Ethics, First online, DOI 10.1007/s10551-015-2968-

Jones, C. and Spicer, A. (2005), “The sublime object of entrepreneurship”, Organization, Vol. 12 No. 2, pp. 223-246.

Jones, C. and Spicer, A. (2009), Unmasking the Entrepreneur, E. Elgar Pub., Cheltenham, UK; Northampton, MA, USA.

Katz, J. and Gartner, W.B. (1988), "Properties of Emerging Organizations”, Academy of Management Review, Vol. 13 No. 3, pp. 429-441.

Kenny, K. and Scriver, S. (2012), "Dangerously empty? Hegemony and the construction of the Irish entrepreneur”, Organization, Vol. 19 No. 5, pp. 615-633.

Kosmala, K. (2013), "Scripting shifts in the regulatory structures: professional competence constructed as a lack", Organization, Vol. 20 No. 4, pp. 577-595.

Kristeva, J. (1994), Strangers to Ourselves, Columbia University Press, New York.

Nietzsche, F. (2001) The Gay Science, Cambridge, : CUP.

Ogbor, J.O. (2000), "Mythicizing and reification in entrepreneurial discourse: ideology-critique of entrepreneurial studies”, Journal of Management Studies, Vol. 37 No. 5, pp. 605-635.

Olaison, L. and Sørensen, B.M. (2014), “The abject of entrepreneurship: failure, fiasco, fraud”, International Journal of Entrepreneurial Behaviour \& Research, Vol. 20 No. 2, pp. 193-211.

Santner, E. (2001), On the Psychotheology of Everyday Life: Reflections on Freud and

Rosenzweig, University of Chicago Press, Chicago.

Sexton, D.L. and Bowman, N. (1985), “The entrepreneur: A capable executive and more”, Journal of Business Venturing, Vol. 1 No. 1, pp. 129-140.

Shane, S. and Venkataraman, S. (2000), "The promise of entrepreneurship as a field of research", The Academy of Management Review, Vol. 25 No. 1, pp. 217-226. 
Shaver, K.G. and Scott, L.R. (1991), "Person, process, choice: the psychology of new venture creation", Entrepreneurship Theory and Practice, Winter, pp. 23-45.

Shubin, D. H. (2001). Monastery Prisons: The History of Monasteries as Prisons. D. Shubin: Xlibris Corp., Philadelphia.

Sköld, D.E. (2010), "The other side of enjoyment: short-circuiting marketing and creativity in the experience economy", Organization, Vol. 17 No. 3, pp. 363-378.

Sliwa, M., Spoelstra, S., Sørensen, B. M. \& Land, C. (2013), "Profaning the sacred in leadership studies: a reading of Murakami's A Wild Sheep Chase", Organization, Vol 20 No. 6, pp. 860880.

Smith, R. and Anderson, A.R. (2004), "The Devil is in the E-tale: forms and structures in the entrepreneurial narratives", in Hjorth, D. and Steyeart, C. (Eds.), Narrative and Discursive Approaches in Entrepreneurship, Edward Elgar Publishing, Cheltenham, UK.

Sørensen, B. M. (2013) "The Method of Juxtaposition: Unfolding the Aesthetic Turn in Organization Studies", in Bell, E., Warren, S., and Schroeder J. (eds.) The Routledge Companion to Visual Organization, London, Routledge, pp. 46-63.

Sørensen, B. M., Spoelstra, S., Höpf, H. and Critchley, S. (2012), Theology and organization, Organization, Vol. 19 No. 3, pp. 267-279.

Sørensen, B.M. (2008), “'Behold, I am making all things new': The entrepreneur as savior in the age of creativity", Scandinavian Journal of Management, Vol. 24 No. 2, pp. 85-93.

Sørensen, B.M. (2008), "St Paul's Conversion: The Aesthetic Organization of Labour", Organization Studies, Vol. 31 No. 3: pp. 307-326.

Steyaert, C. (2007a), “'Entrepreneuring' as a conceptual attractor? A review of process theories in 20 years of entrepreneurship studies", Entrepreneurship \& Regional Development, Vol. 19 No. 6, pp. 453-477.

Steyaert, C. (2007b), "Of course that is not the whole (toy) story: entrepreneurship and the cat's cradle", Journal of Business Venturing, Vol. 22 No. 5, pp. 733-751.

Steyaert, C. and Katz, J. (2004), "Reclaiming the space of entrepreneurship in society: geographical, discursive and social dimensions", Entrepreneurship \& Regional Development, Vol. 16 No. 3, pp. 179-196.

Tedmanson, D., Verduyn, K., Essers, C. and Gartner, W.B. (2012), "Critical perspectives in entrepreneurship research", Organization, Vol. 19 No. 5, pp. 531-541. 
Verduijn, K. and Essers, C. (2013), "Questioning dominant entrepreneurship assumptions: the case of female ethnic minority entrepreneurs", Entrepreneurship \& Regional Development, Vol. 25 No. 7-8, pp. 612-630.

Verduijn, K., Dey, P., Tedmanson, D. and Essers, C. (2014), "Emancipation and/or oppression? Conceptualizing dimensions of criticality in entrepreneurship studies", International Journal of Entrepreneurial Behaviour \& Research, Vol. 20 No. 2, pp. 98-107.

Williams, C.C. and Nadin, S.J. (2013), "Beyond the entrepreneur as a heroic figurehead of capitalism: re-representing the lived practices of entrepreneurs", Entrepreneurship \& Regional Development, Vol. 25 No. 7-8, pp. 552-568.

Žižek, S. (1997), The Plague of Fantasies, London: Verso

Žižek, S. (2000) 'Da Capo senza Fine', in Butler, J., Laclau, E. and Žižek, S., Contingency, Hegemony, Universality: Contemporary Dialogues on the Left, Verso, London.

Žižek, S. (2006a), The Parallax View, MIT Press, Cambridge, Mass. and London.

Žižek, S. (2006b), How to Read Lacan, Granta Books, London.

Žižek, S. (2008 [1989]), The Sublime Object of Ideology, Verso, London; New York.

Zizek, S. (2009), The Ticklish Subject: The Absent Centre of Political Ontology, New Ed edition., Verso Books, London; New York.

Žižek, S. (2012), Less than Nothing: Hegel and the Shadow of Dialectical Materialism, Verso, London; New York.

Žižek, S. (2014), Event: Philosophy in Transit., Penguin Books, Ltd, London. 